This item was submitted to Loughborough's Research Repository by the author.

Items in Figshare are protected by copyright, with all rights reserved, unless otherwise indicated.

\title{
The 'sluice-gate' public sphere and the national DNA database in the UK
}

PLEASE CITE THE PUBLISHED VERSION

http://dx.doi.org/10.1177/0163443711436357

PUBLISHER

SAGE Publications (C) The Author(s)

VERSION

AM (Accepted Manuscript)

LICENCE

CC BY-NC-ND 4.0

REPOSITORY RECORD

Downey, John, Mike Stephens, and Jan Flaherty. 2019. "The 'sluice-gate' Public Sphere and the National DNA Database in the UK". figshare. https://hdl.handle.net/2134/13374. 
This item was submitted to Loughborough's Institutional Repository (https://dspace.lboro.ac.uk/) by the author and is made available under the following Creative Commons Licence conditions.

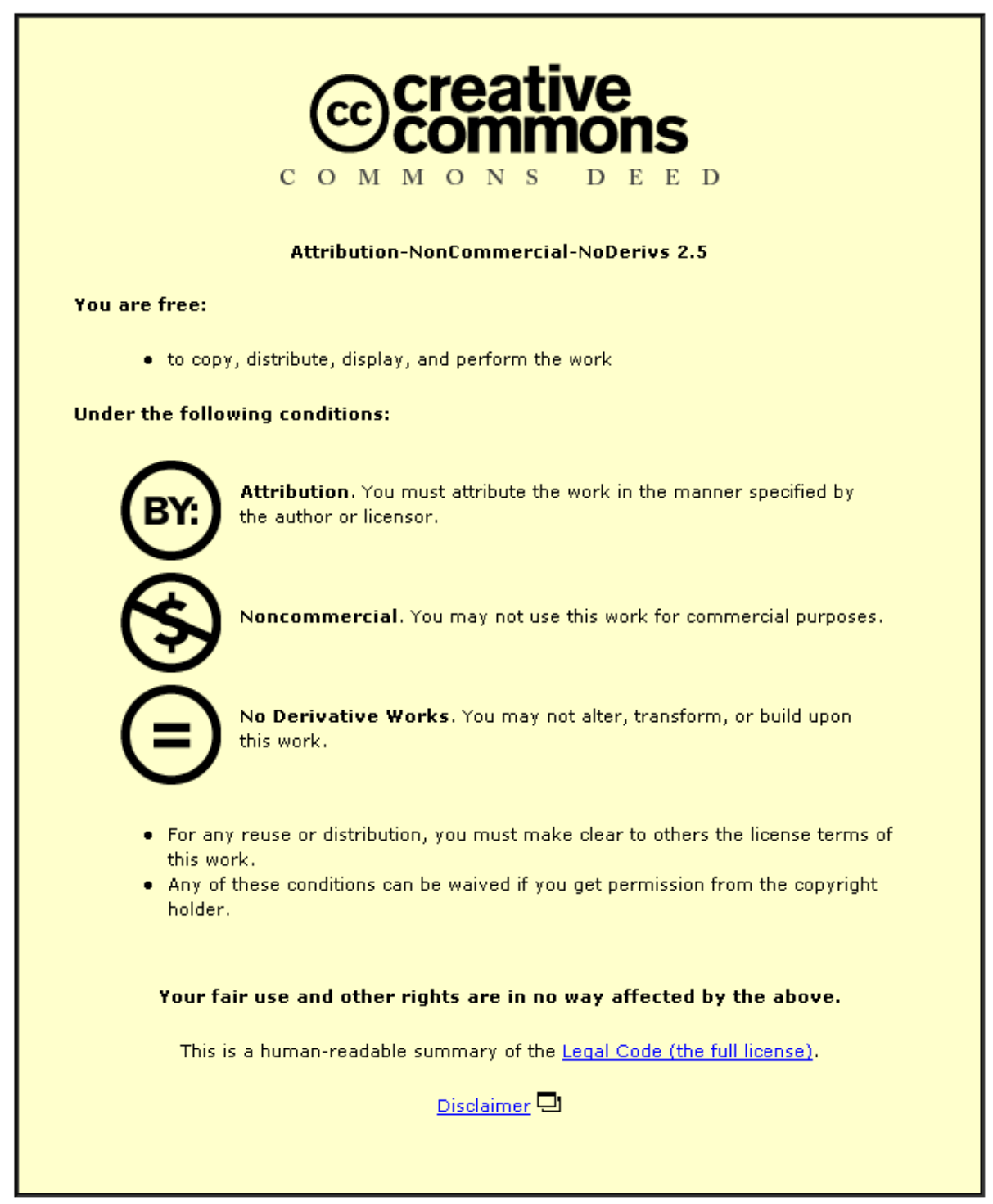

For the full text of this licence, please go to: http://creativecommons.org/licenses/by-nc-nd/2.5/ 


\section{Introduction}

Habermas' amendments to his original public sphere thesis have been recognised by a number of media scholars in recent years (Habermas, 1996; Habermas, 2006; McGuigan, 2002; Davis, 2009 ). His original Habilitationschrift thesis of a decline or re-feudalisation of the public sphere where politics is played out by elites in front of the public (and the consequent imperviousness of systems of instrumental rationality of money and power to criticism from the life-world) has been modified, under the influence of Bernhard Peters’ work (1993, 2007), to incorporate the possibility of action from the periphery of the public sphere influencing, if not exclusively determining, decisions made at the administrative core. This is known as the 'sluice-gate' model of the public sphere and has been greeted with some enthusiasm because it provides the possibility of both explaining and enacting social change from below without which it would appear difficult to fathom how the feminist and ecological movements have influenced public policy.

While Habermas' modification has been noted, there has, however, been limited work on exploring the operation of the sluices in greater detail and particularly on the role of the mass media in acting as a communication channel between peripheral publics and core elites. The purpose of this article is to do so via a case study of the national newspaper debate in the UK about the existence and extent of the national DNA database as it is a prima facie candidate for observing the operation of the sluice-gates. It is simply one case study of the sluices in action but we provide also a model and a method to show how further cases might be investigated so that our thinking about flux in the public sphere might be developed.

\section{The Sluice-gate Model or Modification of the Public Sphere}

In liberal representative democracies, Peters argues, communication and decision-making occur along a centre-periphery channel. Along the channel there are a number of sluices and sluice-gates 
that regulate the flow of communication (a sluice is an artificial channel for carrying water or, in this case, communication). When water pressure builds up behind the gate, the mechanism controlling the opening of the gate is activated and water flows through. The core of the political system is the executive, the judiciary, and the legislature. It is here formal decision-making power resides. The legislature is commonly the most pervious to public intervention but is often weak in terms of ability to address social issues directly and belongs to the outer core. Moving further away still from administrative power there are the institutions of the periphery (associations, cultural and professional bodies, public interest groups, churches, charities). They seek to influence decisionmaking through bringing their concerns before the government, before the courts, before parliament, and before the mass media. The mass media form part of the periphery of the public sphere but they dominate within the periphery through choosing which voices can access the mass media public sphere and thus exercise greater pressure on core public sphere institutions both directly and via the formation of public opinion.

Habermas (2006) argues that there are two critical conditions that mediated political communication (in this case, national newspapers) must fulfil if decision-making is to be regarded as legitimate: the media system should be independent from its social environments and anonymous audiences should give feedback to elite discourses and actors in civil society (2006: 412). While this is the ideal function of the mass media in a deliberative democracy and may be used to assess how well the mass media perform their democratic function, 'the dynamics of mass communication are driven by the power of the media to select, and shape the presentation of, messages and by the strategic use of political and social power to influence the agendas as well as the triggering and framing of public issues’ (2006: 415). For Peters, likewise, democratic legitimacy is achieved in a system where the core is responsive to the periphery. The core institutions obviously hope to control the flow of communication but 'the centre controls the direction and the dynamics of these processes only to a limited degree. Changes can start just as much at the periphery as at the centre' (Peters, 1993: 340). It is this possibility of the periphery acting upon the core institutions through a 
build-up of pressure on the sluices that forces the gates open that explains how policy can change and power can be redistributed in society. Put in Habermasian terms, the life-world confronts the systems world. How much redistribution of power that occurs then depends on the relative strengths of the opposing forces at play and the contexts in which they operate.

Of key importance here is the consciousness of crisis which is communicated (or not) to the public through mass media institutions. If peripheral groups can begin to turn the sluice-gate mechanism, the built up force of the water pours through helping to open the gates further and the gates become more difficult to close. Once this happens it is no longer 'business as usual' for the core institutions. The 'attention span of the citizenry enlarges'(Habermas, 1996: 337) and the core institutions have to respond in some form or other at the risk of losing legitimacy if they fail to do so. We have, in other words, a complex struggle over both the information and political environments. The ability of peripheral groups to influence core decision-making depends on the capability of the peripheral groups (their ability to uncover and present issues from alternative perspectives) and on the opportunities to exercise those capabilities (through interacting via the sluices with government, courts, parliament and the mass media). It may well be that civil society groups are simply too weak because of conditioning by system world imperatives to respond to a crisis by presenting alternatives. However, it should always be borne in mind that the key ideology of liberal democracies is not merely an ideology. Democratic institutions derive their legitimacy from the people and so the core institutions may be ultimately susceptible to popular critique and to popular opinion. In principle, the sluice-gates are always open in a democracy, in practice, they are often more closed than open.

What is proposed here is a different, supplementary approach to examining the relationships between publics, elites, and media institutions than that offered by Lance Bennett. His theory of 'indexing' where journalists take their cue from political elites has been revised to take account of how journalists can sometimes be 'semi-independent' through the dynamic of events not fitting 'official framings'(Bennett et al., 2006: 469). What concerns us here is the process by which the 
concerns of peripheral publics are adopted by political and media elites and elite dissensus is produced through the dynamic relationship of peripheral publics and elites. We need to consider not only the possibility that 'facts on the ground' conflict with official framings but also that carriers of alternative framings need to be present and at least a section of the political elite needs to be prepared to shift its stance. What we offer then is a complex analysis of the dynamic process of indexing rather than say making claims about the degree of independence of the press from political elites.

\section{The UK's National DNA Database}

The national DNA database has become the largest forensic DNA database in the world per capita. It holds genetic profiles from crime scenes, volunteers, convicted persons and, since 2004, merely arrested individuals. The legal basis for the expansion of the database has been through a series of piecemeal Acts and amendments in large criminal justice Bills. The 2001 Criminal Justice and Police Act removed the obligation to destroy DNA profiles if an individual was later released without charge or found not guilty. This Act also allowed DNA to be retained when individuals were charged with a recordable offence. A further Criminal Justice Act in 2003 authorized the removal and indefinite retention of DNA from anyone arrested for a recordable offence, even if released without further action, thus considerably increasing the collection of DNA samples and profiles and adding 'a new 'category' of person to the database: the one time suspect who may never have been charged with a recordable offence and has no criminal record' (Williams \& Johnson, 2008:87). This represents a significant extension in the reach of state surveillance over the general non-criminal populace. As Gerlach notes, 'state agents have gained the right to enter the citizen’s body' (2004:8).

Scotland and Northern Ireland have DNA separate databases but export profiles to the NDNAD. Due to different legislation in Scotland profiles of those acquitted of an offence must be deleted from the database (with the exception of arrestees for serious violent and sexual crimes, which can 
be retained for up to five years). NDNAD profiles are searched on a daily basis to seek a match between crime scene samples and individuals’ profiles. According to Home Office figures in 2007/08, 17,614 crimes were detected in which a DNA match was available (Hansard, 2009). However, these figures do not reveal what part the DNA match played in any crime detection and it is therefore not known how many detections are a direct result of a DNA match between a suspect and a crime scene, how many aided the investigation and how many were superfluous to detection.

Currently, more than 5 million individuals, approximately 8\% of the UK population, are on the database. Of those on the NDNAD nearly one million (986,185 persons), $21 \%$ of the estimated total on the database, have no conviction, caution or reprimand on the Police National Computer (Hansard, 2009a). However, the indefinite retention of unconvicted people's DNA and fingerprints was ruled illegal by the European Court of Human Rights in December 2008. Initial attempts to retain profiles for twelve years were undermined by a poor evidence base (Home Office, 2009) and growing political resistance by the Conservative and Liberal Democrat parties but with a looming General Election the Crime and Security Act was passed in April 2010, securing the retention of unconvicted people's DNA records and fingerprints for 6 years and Police National Computer records for an indefinite period. Profiles of convicted persons, including children who commit serious crimes, would also be kept indefinitely under this law.

The reach of the DNA database became an issue in the 2010 General Election campaign. The Labour Party claimed that the Conservatives and Liberal Democrats because of their plans to limit its reach were being 'soft' on crime. The formation of a Conservative and Liberal Democrat coalition government after the 2010 General Election led to the 2011 Protection of Freedoms Bill that will see the DNA profiles of those not charged or those acquitted destroyed within one month except for those charged with having committed serious violent or sexually-related crimes (in which case the profiles may be kept for three years, extendable to a maximum of 5 years on application to a court, before being destroyed). The DNA of those arrested (but not charged) with serious violent or sexual crimes may be retained for three years (extendable to 5 on application to court) if the 
Home Secretary applies and convinces a newly created commissioner for biometric information that such retention is justified. The DNA profiles of innocent people currently on the database (about 1 million profiles) will be deleted.

\section{Methodology}

Three methods were used in our research. An analysis of claims-making in the newspaper debate from January 1991 to May 2009 was followed by in-depth interviews with key actors central to the debate, identified from the analysis of the newspaper coverage. In addition, the method of processtracing, deployed in case study analysis in comparative political research but not used before in media analysis, was adopted because it is an appropriate method to identify the causal path through which the sluice-gates open.

\section{Claims-making}

Notwithstanding the manifold problems of electronic databases, we used the Nexis database, which has electronic copies of many UK newspapers (Deacon, 2007). A keyword search for 'DNA database’ was performed for the research period, January 1991-May 2009. We harvested articles from national daily newspapers in England, Scotland, Wales and the Belfast Telegraph, The Irish News, Belfast News Letter and Irish Examiner from Northern Ireland. The search term retrieved 2693 articles mentioning the DNA database in newspapers over the study period in which 1643 claims were documented (1310 with a key word). Articles were categorised by newspaper, claimsmaker, claim , valence (broadly whether a claim was supportive or critical of the DNA database) and key words.

Our work draws on the insights of claims making (Best, 1987) and political claims-making analysis (Koopmans \& Statham, 1999; Statham \& Gray, 2005a) to understand the media debate. 
By making claims, collective actors strategically attempt to make their political demands appear more publicly rational and legitimate than those of their opponents [...] An instance of political claims-making is a unit of strategic action in the public sphere. It consists of the purposive and public acts which articulate political demands, decisions, implementations, calls to action, proposals [and] criticisms... (Statham \& Gray, 2005b: 881).

\section{Interviews}

From the newspaper analysis we identified a number of key actors central to the debate. Interviews were conducted with ten of the central protagonists including MPs: David Davis, Chris Huhne and Jenny Wilmott, the current and past chair of the National DNA Database Strategy Board and interest groups, such as Liberty, GeneWatch and No2ID, enabling us to examine public claims in greater depth.

\section{Process-tracing}

Process-tracing as a method of case study analysis has a relatively long history in political science and political sociology (George, 1979). It is suitable for single case analysis such as this one that can draw upon longitudinal evidence. Process-tracing has not yet been adopted in media analysis and deserves greater attention from media scholars. The variety of process tracing used here is that of analytic explanation (George and Bennett, 2005: 211). Here a historical narrative (in this case the media history of the DNA database) is converted into an analytical causal explanation by selecting factors that researchers consider to be important for explaining the matter at hand and producing a compelling account of the causal process involved. 


\section{Opening the media sluice-gates}

As mentioned in the introduction, we consider this case as a prima facie candidate to provide further elaboration of the sluice-gate model of the public sphere. The DNA database attracted little media attention before 2006 and that attention was largely, though not exclusively, supportive and focused on CSI-style reporting (see Cavender and Deutsch, 2007: 68) of the use of DNA in solving major crimes such as murder and rape (whereas the database is mostly used in mundane, so-called 'volume crime’ such as burglary and car theft). Opponents of the database were cast as middle class liberals, friends of criminals, and as being out-of-touch with the harsh realities of contemporary Britain. Helen Wallace from GeneWatch describes the dominant framing of the issue that portrayed opponents as 'Minority, middle class, you know, this kind of stereotype.'

Chart 1: Claims per year UK national daily and Sunday newspapers

Senior Conservative and Liberal Democrat politicians, when asked about the lack of media and parliamentary scrutiny of the database before 2006 when their parties were in opposition, refer to the 'macho' parliamentary and political culture where any mention of the threat to civil liberties posed by the database would be seen as being 'soft on crime'. During this period there was essentially a competition between the government and the Conservative Party for whom could be tougher leading to an ever greater erosion of civil liberties. David Davis, a decidedly right-wing 'macho' politician, when asked why there was so little parliamentary scrutiny of the 2001 and 2003 legal changes to the retention of DNA replied:

Because it's a macho argument that's gone on between the parties. Who can be tougher on crime? Who can be tougher? At the time this was happening, worse afterwards, but the time this was happening, there was a great butch debate about who was going to be hardest on the criminal. 
It would be wrong, however, to suggest that there was no opposition to the database even from some unlikely sources. The right-wing mid-market paper Daily Mail, not noted for being 'soft on crime', published a news article in March 2003 about the change in law that would mean an increase in the number of innocent people’s DNA profiles on the database quoting Liberty, Simon Hughes Home Affairs’ spokesman of the Liberal Democrats, and Conservative spokesman Dominic Grieve who all criticised the change. This is very significant for our explanation as it shows that the intellectual lines of the argument were clearly drawn as early as 2003 with both the opponents and supporters of the database in place (Government and police versus Liberal Democrats, Conservatives and civil liberty groups) but media and political scrutiny of the DNA database did not intensify until 2006.

From 1991 to May 2009 we coded 1643 claims for keywords that were used by claim-makers to convey their positions to audiences succinctly. Before 2006 references to solving or fighting crime were the most dominant keywords, appearing in $19 \%$ of all claims. Reference to innocent people on the database, in contrast, made up only 9\% of keywords. From 2006 this situation was dramatically reversed. By May 2009 23\% of all keywords referred to the presence of innocent people on the database while only $11 \%$ of keywords referred to solving crime. This indicates a considerable shift in the discourse surrounding the database: before 2006 it was essentially seen as a crime-fighting tool, after 2006 it became a threat to civil liberties. Associated with the rise of concern for the number of profiles of innocent people held on the database was a broader frame concerning the relationship between the state and the citizen. From 2006 onwards the language of 'surveillance' and 'Big Brother' associated with authoritarian state action became common so that by May 2009 there had been 146 mentions over the 18 year period. There had been only 3 references to ‘surveillance’ prior to 2006.

This is evidence of the sluice-gates of the public sphere opening with respect to civil liberties. An issue that existed on the periphery of the public sphere penetrated the mass media and other more core institutions of the public sphere such as the legislature and judiciary. How and why did 
the mass media sluice-gates open in 2006 and why did they remain open at least until the 2010 General Election? We identify the presence of four causes that combine to form a causal recipe in order to explain the opening of the mass media sluice-gates of the public sphere in 2006: peripheral civil society actors; a resonant media narrative or narratives; trigger events; and receptive actors in the core public sphere institutions.

\section{Civil Society Actors: voices from the periphery}

If we examine the opponents of the database who made it to the national newspapers during a period when coverage of the database was decidedly muted and largely supportive (in other words, it was mostly perceived by the media not to be a contentious issue), we find that civil liberties groups and scientists were to the fore. Few journalists and politicians opposed the extent of the database. Conservative Shadow Home Affairs minister Ann Widdecombe was the first MP of any party to raise the issue of civil liberties and the database in 2001. Her opposition did not spark significantly greater interest from other MPs (there were some exceptions such as Liberal Democrat MP Simon Hughes) until the database became a major civil liberties issue for mass media and politicians in 2006.

\section{Charts 2 and 3}

The issue of the profiles of innocent people being retained on the database was first raised in the mass media by the civil liberties group Liberty in May 1998. Liberty made more claims about the presence of innocent people’s profiles reported by national newspapers in 1999 (twice), 2001, and 2003 (twice). Observer journalist Nick Cohen also raised the issue of the innocents in 2003 when he discussed the possibility of the database being used in 'fishing expeditions' to trawl the DNA of suspect groups (the possibility, for example, of police deciding to arrest someone in order to get a permanent DNA record of that person to check against existing and future evidence). Another 
Observer journalist, Henry Porter, twice criticised the erosion of civil liberties that the database represented in 2003. Even these noted commentators and independent advocates of civil liberties, however, only mentioned the database once or twice.

The media presence of one NGO - Liberty - far outweighs others such as Genewatch, No2ID, and Privacy International. Liberty have been established for over 75 years, they have a staff, they are based in London, have high profile supporters, and tend to focus their campaign work on briefing media and political elites. The other organisations are of much more recent origin, smaller often relying on volunteers with much smaller budgets. Genewatch is not based in London but in a small spa town in Derbyshire, Buxton. Liberty tend to focus their activity on lobbying political contacts and on media campaigning. They work within the elites of the core institutions and of the media and are distant from grassroots campaigning. Isabella Sankey, the policy director of Liberty, emphasised the amount of behind the scenes media work that is undertaken:

'I mean I know the way that our press work breaks down is that we spend a lot of time doing background briefing for journalists. And that will be just objectively giving information as well as giving them kind of our slant or our side of the story or what we think the issues are. And I think the DNA Database is, as I say, because it's quite a technical and can be felt to be a bit of a legalistic issue, there's sort of lots of things to get your head around if you're new to it. We do brief journalists on the DNA Database, you know’.

The focus of Liberty on influencing media and political elites and their success in this area is noted by Helen Wallace from GeneWatch: ‘campaigns like the No2ID Campaign that’s really tried to engage people at the grassroots level rather than just have a more elite kind of debate that, you know, Liberty has tended to have in the past, you know. I mean I think they do a great job, but they do a job that's very much focused on the legal profession and parliamentary lobbying and particularly lobbying in the Lords, which does not then tend to engage people on the streets, except in the context of legal cases of course where they're supporting individual cases'. 
We can conclude from this that some peripheral public sphere actors are more central than others. The media much prefer to pay attention to relatively well-funded and organised NGOs who are based in the capital and who have a 'respectable' history of campaigning. They are generally regarded by media professionals as potentially useful, legitimate, and authoritative sources. It is true that some very small organisations do get some media attention (particularly from 2006 onwards) and this is often the result of the work of energetic and knowledgeable individuals often running ‘spare bedroom’ operations such as Helen Wallace from Genewatch, Simon Davies from Privacy International, and Phil Booth from No2ID.

Members of the public very rarely feature in the coverage. Those that do are either the 'victims' of the database (often the mothers and fathers of innocent children campaigning for their DNA to be removed) or victims of crime or fathers and mothers of victims who are campaigning in favour of the database. The presence of 'ordinary people’ is often associated with NGO and/or newspaper campaigning. For example, The Sun ran a 'Mothers in Arms' campaign featuring the mothers of three high-profile victims of crime arguing for longer prison sentences, the return of the death penalty, a universal DNA database, and so on (The Sun, March 122008 http://www.thesun.co.uk/sol/homepage/news/justice/article905439.ece). This is a tactic increasingly used by governments and opposition parties. The mother of Sally Ann Bowman, a murder victim, was cited by the Labour Home Secretary Jacqui Smith to support the government's policy of retention.

It would be easy and to some extent wrong to conclude that newspapers are not interested in the views of ordinary citizens. They are interested in people (often in an instrumental way to further the causes backed by the newspaper through publishing human interest stories) who have been affected by the database and it is commonly those individuals who decide it is in their best interests not to be present in the media. Newspapers are almost never interested in the opinions of 'ordinary citizens' who are not directly affected. They tend to regard ordinary citizens as providing human interest 
stories and other material that can then be commented upon by experts from NGOs, political parties, journalists and so on.

\section{Resonant Narratives: innocent and children first}

An essential part of the job of a NGO that wishes to persuade mass media institutions to report on an issue is to select an element of the issue that may be of interest to journalists. They fashion a narrative that they hope journalists will pick up on and disseminate via newspapers and television. Once that narrative has been accepted then subsequent NGO work may be more reactive, especially on an issue that has been widely reported such as the DNA database: Liberty 'on the DNA Database issue, I think we get a lot of press interest. And I feel with this particular, you know, out of all the issues that we do, this is one of those where there's been quite a strong kind of media narrative and the media have become... well certain elements within the press are very keen on the idea, feel very strongly about it and are very willing to do stories on DNA. So I think out of all of our stories, one of the ones where there is probably the strongest media narrative. And so a lot of the work that we do is kind of reactive to press interest that we get.'

There are many possible stories to be told about the national DNA database that could be used by supporters and opponents. The type of story promoted by its supporters will emphasise the role that DNA evidence and the database played in solving a significant crime (rape, murder and so on). Opponents tend to focus on two types of story - the presence of children (often thought to be naturally innocent or at least of not deserving of punishment because of dominant perceptions of childhood) on the database and the presence of profiles of innocent people on the database. There are many other stories that could be told by opponents but these are often not told because of a perceived lack of resonance for one reason or another.

The disproportionate presence of innocent black males on the database, for example, is an issue that has received some media attention but much less than the issue of innocent or children on the 
database. Such data obviously has broader implications than simply the DNA database as it raises the contentious issue of institutional police racism. Around one third of the UK's black population have a DNA profile on the database and three-quarters of young black males are on the database. Innocent black men are disproportionately represented on the database. This has prompted some speculation that some police are engaged arresting certain categories of people without reasonable suspicion with the intention of solving past or future crime. However, a narrative of the unjust retention of innocent people's DNA has more resonance in a state where there is presumed innocence enshrined in law rather than a narrative than accuses the police of racism as this claim will provoke both committed support and hostile rejection from different sections of the media and the public as a whole.

Another narrative that could be used is one that argues that the DNA of released prisoners should be taken off the database on the grounds that the punishment has been completed and so DNA retention is unwarranted discrimination and at odds with the ideal of rehabilitation. The permanent retention of DNA profiles can be seen as part of a 'new penology' of actuarial justice, risk management, and a return to retributive rather than rehabilitative justice (Harcourt, 2007; Garland, 2001; Sapir, 2008).Such a narrative would more than likely fail to resonate with media and public alike as criminals are often thought to have forfeited their rights in perpetuity. Civil liberties organisations may well consider the police to be racist and the permanent retention of convicted people's DNA to be unwarranted but this is not the ground they choose to argue on as they do not think they can 'win' or even attract media interest. Phil Booth of No2ID explained how his organisation's media narrative has moved away for the present from the issue of rehabilitation of prisoners and has been adapted to fit what No2ID think is a winnable argument: 'You don’t you don't, the only time I've ever had any media interaction on this I was attacked by David Aaronovitch and he said like why are you campaigning for the rights of criminals which actually boiled down to well (in private not a public forum) I hope when we've won our current battle which as campaigners we have to focus on what's winnable at the next stage then you will come out then and say yes and now's the time to campaign for the taking off of people's DNA for people that have served their time. That side of the debate as you say 
is not even entered into and yet I think in this country we like to think of ourselves as liberal. It doesn’t appear. I mean we have laws on the rehabilitation of offenders and yet the systems counter that exactly.'

The move toward the political centre of the argument is also true for proponents of the database as well. Before the rise of opposition to the database there were a number of calls for a universal database. As opposition has grown the state has withdrawn such calls while attempting to hold the line of the retention of innocent people's DNA profiles. Each side chooses the position that it thinks will have the greatest public resonance and this means that the argument actually occurs somewhere in the middle and the differences between the positions become squeezed even if the language used emphasises differences between competing positions.

The presence of organisations such as Liberty and the presence of a resonant narrative do not in themselves lead to the opening of the media sluice-gates. Liberty has existed for many years and the narrative concerning the presence of innocent people on the database was available in 2001, five years before the DNA became an issue for the mass media.

\section{Triggers: when 'events' become 'media events'}

Media coverage tends to spike in months where there is a newsworthy event associated with the DNA database. In April 1995 there was limited coverage of the database as it came into existence and in August 1995 when the database was used identified a person later convicted of burglary. There was a spike in media attention in March 2003 during the parliamentary debates concerning the retention of DNA on arrest. In September 2007 the call for a universal database by Justice Sedley prompted a newspaper debate. In February 2008 there were three high profile murder convictions in which the DNA database played a part. In December 2008 the European Court of Human Rights ruled against the UK in the S and Marper case, two innocent people whose profiles are on the database, criticising the 'blanket and indiscriminate retention' of DNA. In May 2009there was a spike in coverage when the Home Office responded to the ECHR ruling.

Convictions, court rulings, the publication of figures in parliament, parliamentary reports and debates and so on are all moments of heightened media attention where competing actors struggle with one another and with media professionals to deliver to the public their arguments. Many of these events are recurring (high profile convictions, publication of reports and so on). Before 2006 media attention tended to be of low intensity and died away quickly after the event. The month of greatest coverage of the database was 
September 2007 which saw competing calls for a universal database and a Human Genetics Commission report that called the retention of innocent people's DNA profiles 'disproportionate'. With such coverage the issue reaches a broader range of media and political elites and a broader public. A critical mass has been attained which means that the next event receives more media attention than previous, similar events as journalists and political elites are primed for the story. A momentum develops when members of the core institutions of the public sphere (members of Select Committees in parliament, for example) decide that there is an issue to be discussed and their work becomes an event for media professionals to report on.

Once a critical mass or tipping point has been reached media professional tend to go to sources rather than sources going to media professionals. NGOs after years of attempting to interest newspapers in the database were now approached by newspapers for comment. Isabella Sankey of Liberty describes this phenomenon and dates the change to the ECHR ruling on S and Marper in December 2008:

Maybe post-Marper I think there's been a particular spike actually yeah, because that story itself was really big. I remember the day that Marper broke, we were all... We normally have sort of one spokesperson on a story if it's a heavy media day, and on that day I think we had four people because we just got absolutely inundated. It was, I think perhaps the busiest press day we've had since I was here...since then, whether it's been yeah, a report by the HGC or there's been FOI requests made by politicians, whatever it is, there's been quite a lot of activity by interest groups I guess, but I think the press have been keen to kind of make a story out of it.

After the ECHR ruling relatively insignificant events such as a report attract greater media attention because the issue is more widely understood and considered to be newsworthy by media professionals. These events are now placed into a broader narrative of the erosion of presumed innocence and the rise of the surveillance society whereas previously they were reported as stand-alone events and not seen either as symptomatic of government policy or a general malevolent trend. Liberty ‘when something does come along, they're very keen to take it up and I think we've almost been quite surprised in the last 18 months or so on 
just how proactive the press will be in carrying a story, pushing it to the top of the agenda and asking us to come in and comment.'

\section{Receptive Media and Political Elites}

So far we have discussed three ingredients of the causal recipe that explain the opening of the mass media sluice gates. While these ingredients are necessary they were not sufficient, at least in this case, to open the sluice gates by themselves. If they were sufficient the sluice-gates would have opened well before 2006 as the ingredients were present from 2001 onwards. The missing ingredient is the remarkably heightened receptivity of political actors from core public sphere institutions and of journalists.. These are related as journalists tend to see contentious issues within core public sphere institutions such as parliament or the legal system as inherently newsworthy events. This explains how issues are either largely ignored or gather media and political momentum.

As our analysis of newspapers had clearly revealed an escalation of media attention from 2006 onwards we asked core political actors why they thought this was the case. Chris Huhne, then Liberal Democrats Home Affairs spokesman, reflected on possible explanations for the spike in media attention:

$\mathrm{CH}$ : When was the Conservative leadership election?

Interviewer: I couldn't tell you that I'm afraid.

CH: Because it would also... Cos David Davis became...

David Davis became the Conservative spokesman. Did he start doing things on DNA? 
Interviewer: Yeah.

When did Nick become... Home Affairs. Um-hum. You said it was 2006 it started?

Interviewer: That's right. And it escalated dramatically then. And then most of... a lot of the newspapers started being much more sympathetic towards the sort of antiDNA Database [Unclear - 00:13:51] shall we say. That's when there was a whole rise of the word innocent really in relation to the database.

CH: Well I would suspect, I don't know, but there were two... I mean there were two leadership elections. One in our party and one in the Tory Party. The Tory Party one was first in 2006 I think, or was it late 2005?

Chris Huhne refers to David Davis, a right-wing Shadow Home secretary from 2003 to his resignation to fight the bye-election on the issue of civil liberties in 2008. He was a candidate for conservative Party leader but came second to David Cameron in December 2005. David Davis has the most claims of any individual in the newspapers we surveyed with 50 claims. When asked about why the debate did not develop until 2006 he states that his own position before then was unclear:

Interviewer: Okay. So you had your stance. You just didn't have a hook to hang it on?

DD: No, no, no. The design of the stance took time. I was not certain myself of the argument. For a start we didn’t know... initially we didn’t really know how many people were...er Well firstly we didn’t have any sort of unconvicted there were. Getting that data 
out took some time erm, in the earlier part of this. And then later on I was mulling over in my mind whether the unconvicted were innocent.

Davis is acknowledging here that it took time for him (and the Conservative leadership) to be convinced of the narratives put forward by Liberty and other civil liberties groups and also that there needed to be a trigger event such as the discovery of the extent of retention of innocent people's profiles on the database to crystalise the attention of politicians, journalists, and indirectly the public.

In 2005 Davis led the opposition to the Labour government's plans for 90 day detention of people suspected of terrorism and opposed the government's plan to introduce identity cards. He describes these campaigns as a two-way fight as the Conservative Party was divided between authoritarian and libertarian positions. The authoritarian wing of the Party that believes in a strong state and free market was ascendant under Thatcher and Thatcherite traditions were still prevalent under the leadership of Michael Howard who resigned after the 2005 General Election defeat.

The third consecutive defeat of the Conservative Party at the General Election in 2005 persuaded many in the Party, belatedly, that a decisive shift in party policy and image was required (Bale, . The election of David Cameron as leader in December 2005 led to a rebranding of the party. One aspect of this rebranding has been a concern with protection of civil liberties. This was a way for Cameron to distinguish the new Conservative Party not only from the old one but also the Conservative Party from the Labour government. He sought to replace the populism of being tough on crime with a policy of opposing the 'Big Brother' state. In other words, the right-wing libertarian tradition within the Conservative Party that had been largely submerged in recent decades seized the possibility of picking up civil liberties concerns from largely left-wing libertarian and liberal NGOs in an attempt to refashion the party in the eyes of the electorate. This is not to dismiss the shift towards a concern for civil liberties as merely political opportunism but there was a substantial element of political opportunism at play. 
Helen Wallace from GeneWatch remarks on the importance of the Conservatives changing their stance on the database and the role that NGOs played in that in relation to the issue of innocent children’s DNA profiles being retained:

Interviewer: Oh right yeah. Yeah. Innocent children yeah. It could have been September.

HW: Yes. That could have been. Yeah. Yeah. So that was, you know, partly linked with, you know, a deliberate attempt to get the Conservative Party onside [laughs]. I mean they were onside politically, but yeah you know, they were obviously also... I mean all the politicians from all parties were nervous about being seen to be soft on crime [Unclear 00:16:53] about the database. So we had to deal with that issue.

Civil liberties groups also lobbied right-wing newspapers who had previously prided themselves on being tough on criminals and supporting the database. While The Sun remained steadfastly in favour, the Daily Mail the right-wing mid-market newspaper embraced the civil liberties agenda. Helen Wallace describes the shifting positions of right-wing newspapers:

Is there any papers that have not taken you up at all, you know?

No I don't think there are, but there was a... You know, there's been a shift over time in positions in editorials.

Yeah. Yeah. I've seen that. 
As you've probably noticed, but yeah, in terms of who was covering. So it made quite a difference when the Daily Mail decided to get on the case on that cos it's coincided with us sort of talking to the Tories really about the issue.

\section{When was that? Was that more recently?}

Yeah. That was for later. So let me try and think. Well the point at which it really... Ah no, the first story we did with the Mail, the one Action Rights For Children about our estimate that a 100,000 innocent children were on the database and that was in the summer of... I'm losing count now. Where are we now [laughs]? Might have been summer 2007 I think.

Under Cameron's rebranding of the Conservative Party authoritarianism was dropped in favour of a concern for civil liberties and the right-wing press largely fell into line adopting the language of the left on civil liberties (Big Brother, surveillance state and so on) in an effort to generate a narrative capable of resonating with the electorate. Without this perceived need to rebrand the Conservative Party after successive General Election defeats it is highly unlikely that the media sluice-gates would have opened. Without the enhanced receptivity of political actors from core public sphere institutions, the gates would have remained firmly closed. This enhanced receptivity was made possible by the prior existence of a submerged strain of Conservative Libertarianism and also a belief in the electoral potential of such a rebranding i.e. that the interests of the Party would be further through this.

\section{Conclusion}


Habermas' revision of his public sphere thesis inspired through the sluice-gate metaphor and work of Bernhard Peters is a welcome elaboration of thinking about the public sphere. Rather than thinking about the sluice-gates as a new model of the public sphere it may be better to think of it as a modification of Habermas's original concept. This modification offers the potential to explain how change occurs in the public sphere and how peripheral actors can, on occasion, help to bring about change in core public sphere institutions. Clearly the public are not completely divorced from elites in the manner suggested by Habermas’ original thesis. However, there has been relatively little empirical elaboration of the operation of the sluice-gates.

The present study is a contribution to the development of an empirically informed sluice-gate modification to the public sphere concept but more empirical work is obviously required. The present approach of suggesting a causal recipe or combination for how mass media sluice-gates are opened, namely examining the interaction of peripheral civil society actors, narratives, trigger events and recruitment from the core of the public sphere, may prove to be a useful way of approaching other case studies. Emphasis should be placed upon explaining the interaction of actors and institutions situated in different parts of the public sphere that produces changes in the public sphere and may lead to broader policy and/or social change. It is important to capture the dynamic relationships between actors and institutions from periphery to core if we are to avoid a simplistic, mechanistic account of the sluices opening and closing.

While one should be wary of drawing general conclusions from one case study as the balance of forces will undoubtedly vary from issue to issue and from time to time, it is important to make five observations that may help to focus future research on the sluice-gate modification. The first is that when we speak of peripheral public sphere actors we should recognise that the key 'peripheral' civil society group in this case, Liberty, is a relatively well-funded organisation that lobbies elites in mass media and core public sphere institutions. It enjoys much greater access to the mass media and to political elites than other NGOs working this area. The voices of GeneWatch and No2ID were 
heard but only rarely and often only after the database had become a story for journalists. Some peripheral actors are then more peripheral than others. The voices of ordinary citizens were largely absent and when they were present this could be explained by their supposed compatibility with the newspapers' agenda. Second, the search for a resonant narrative by peripheral actors often means that some important issues are ignored because they are not seen as being 'winnable' and often the most vulnerable and downtrodden are ignored because to speak out for them would fail to resonate with broader publics. The focus on the civil liberties of the innocent in this case has crowded out issues such as police racism and the rehabilitation of prisoners. Third, the opening of the sluicegates occurred because the Conservative Party, the major opposition political party in the UK at the time, needed to reinvent itself for electoral purposes and civil liberties issues were one way of doing this. The turn to civil liberties was convenient because it allowed the new Conservative leadership to distance themselves from previous Conservative governments and the Labour government. It turned its back on three decades of being associated with authoritarian state policies and being 'hard on crime' and embraced the discourse of the libertarian left in its critique of the surveillance state. In other words, without this perceived need to change amongst a significant section of the political elite that change served its own interests then the sluice-gates would have remained firmly shut. The Conservative Party did not control the discourse but rather adopted the discourse and this explains why the sluice-gates opened. Fourth, once a tipping point has been reached, more core political actors discover the issue and this in turn brings greater media attention and attention from other elites. Understanding fully the generation of this momentum is far from a trivial undertaking. Fifth, the opening of the sluice-gates of the various institutions - media, legislature, judiciary - tend to be related to one another in a mutually reinforcing way (for example, media attention leads to more individuals raising issues with their representatives who then raise the issue in parliament and this is then reported on by the mass media). For all of these reasons, it is better to talk of a sluicegate modification to Habermas’ original conception rather than an entirely new model of the public sphere. 


\section{References}

Bale, T. (2010) The Conservative Party From Thatcher to Cameron. Cambridge, Polity

Bennett, L., Lawrence, R. and Livingston, S. (2006) 'None dare call it torture: indexing and the limits of press independence in the Abu Graib scandal' in Journal of Communication 56 pp467-485 Best, J. (1987) 'Rhetoric in Claims-making: constructing the missing children problem’ Social Problems 34(2) 101-121

Cavender, G. and Deutsch, S.K. (2007) ‘CSI and Moral Authority’ Crime, Media, and Culture 3(1) 67-81

Davis, A. (2009) ‘Evaluating communication in the British parliamentary public sphere’ British Journal of Politics and International Relations 11(2) 280-297

Deacon, D. (2007) ‘Yesterday’s Papers and Today’s Technology: Digital Newspaper Archives and 'Push Button’ Content Analysis’ European Journal of Communication 22(1) 5-25

Habermas, J. (1996) Between Facts and Norms. Cambridge, Polity.

Habermas, J. (2006) 'Political Communication in Media Society: Does Democracy still enjoy an epistemic dimension? The impact of normative theory on empirical research' Communication Theory 16 411-426

Koopmans, Ruud and Statham, Paul (1999) 'Political Claims Analysis: Integrating Protest Event and Political Discourse Approaches', The International Journal of Research and Theory about Social Movements, Protest and Collective Behavior 4(2): 203-221.

McGuigan, J. (2002) ‘The Public Sphere’ in Hamilton, P. and Thompson, K. eds The Uses of Sociology. Oxford, Blackwell

Peters, B. (1993) Die Integration moderner Gesellschaften. Frankfurt am Main, Suhrkamp

Peter, B. (2007) Der Sinn von Öffentlichkeit. Frankfurt am Main, Suhrkamp 
Statham, Paul and Gray, Emily (2005a) 'The Public Sphere and Debates about Europe in Britain', The European Journal of Social Science Research 18(1): 61-81.

Statham, Paul and Gray, Emily (2005b) 'Becoming European? The Transformation of the British Pro-migrant NGO Sector in Response to Europeanization', Journal of Common Market Studies 43(4): 877-898.

Williams, R. and P. Johnson (2008). Genetic policing: The use of DNA in criminal investigations. Devon, Willan Publishing. 
Chart 1: Claims per year UK national daily and Sunday newspapers

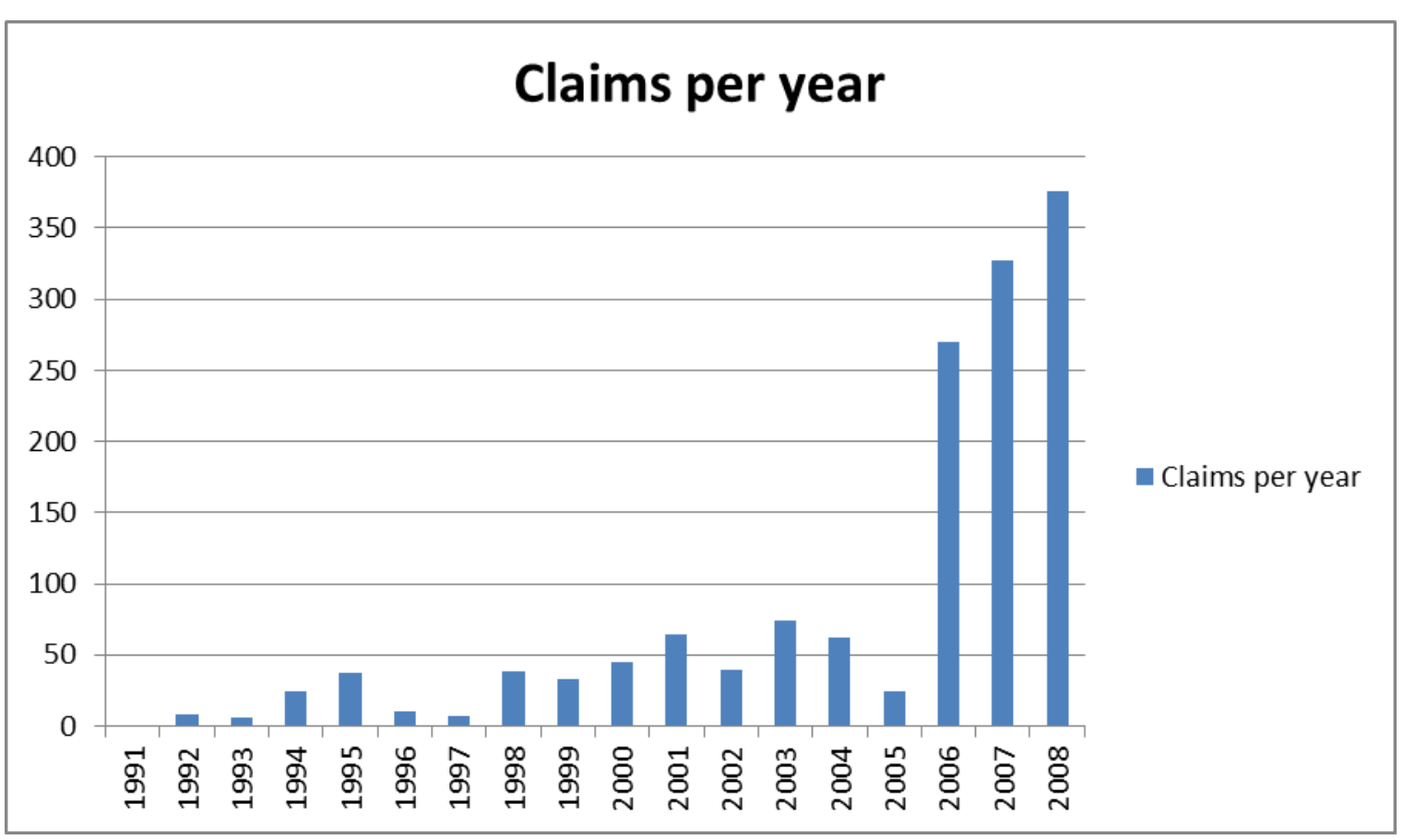


Chart 2: Opponents to the DNA database in national newspapers 1991-2005

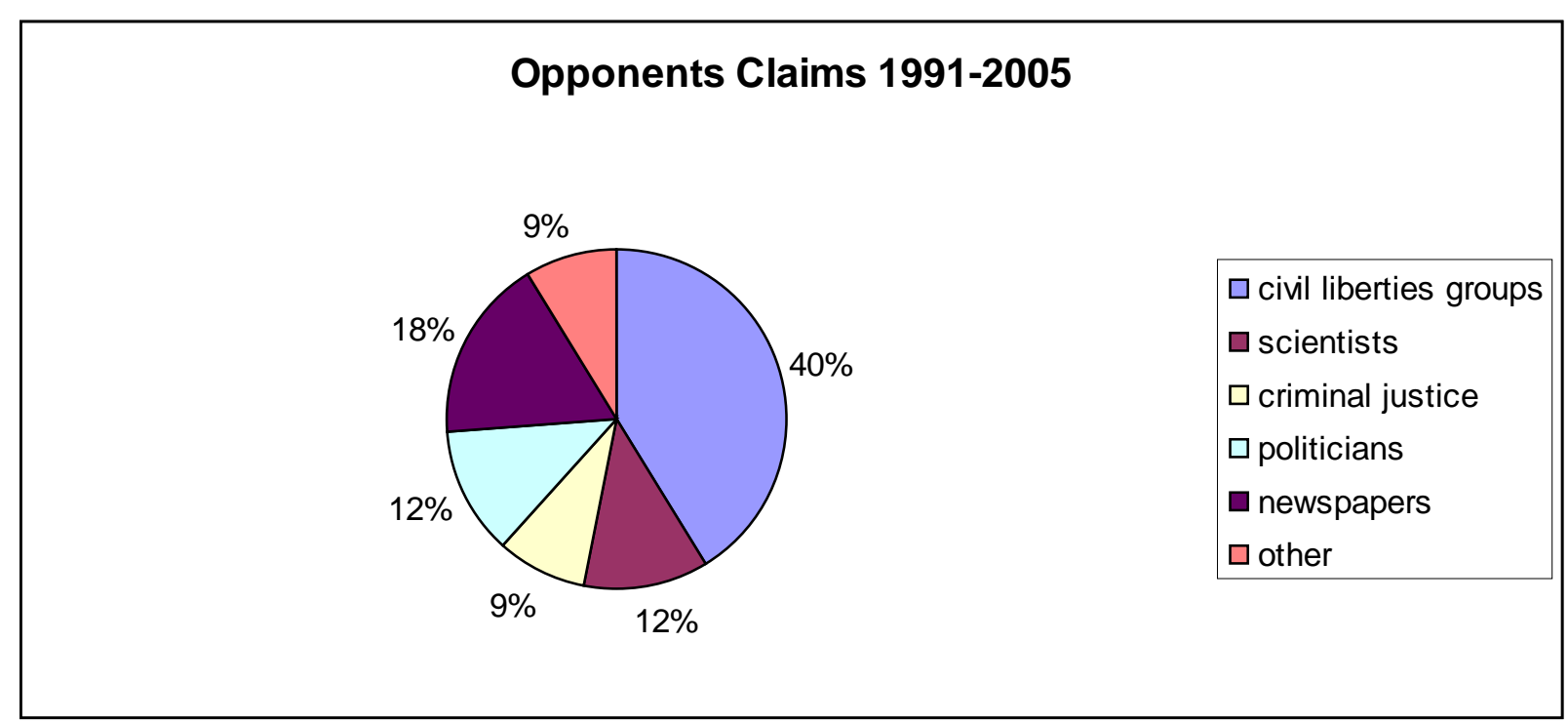

$\mathrm{n}=398$ 
Chart 3: Opponents to the DNA database in national newspapers 2006-9

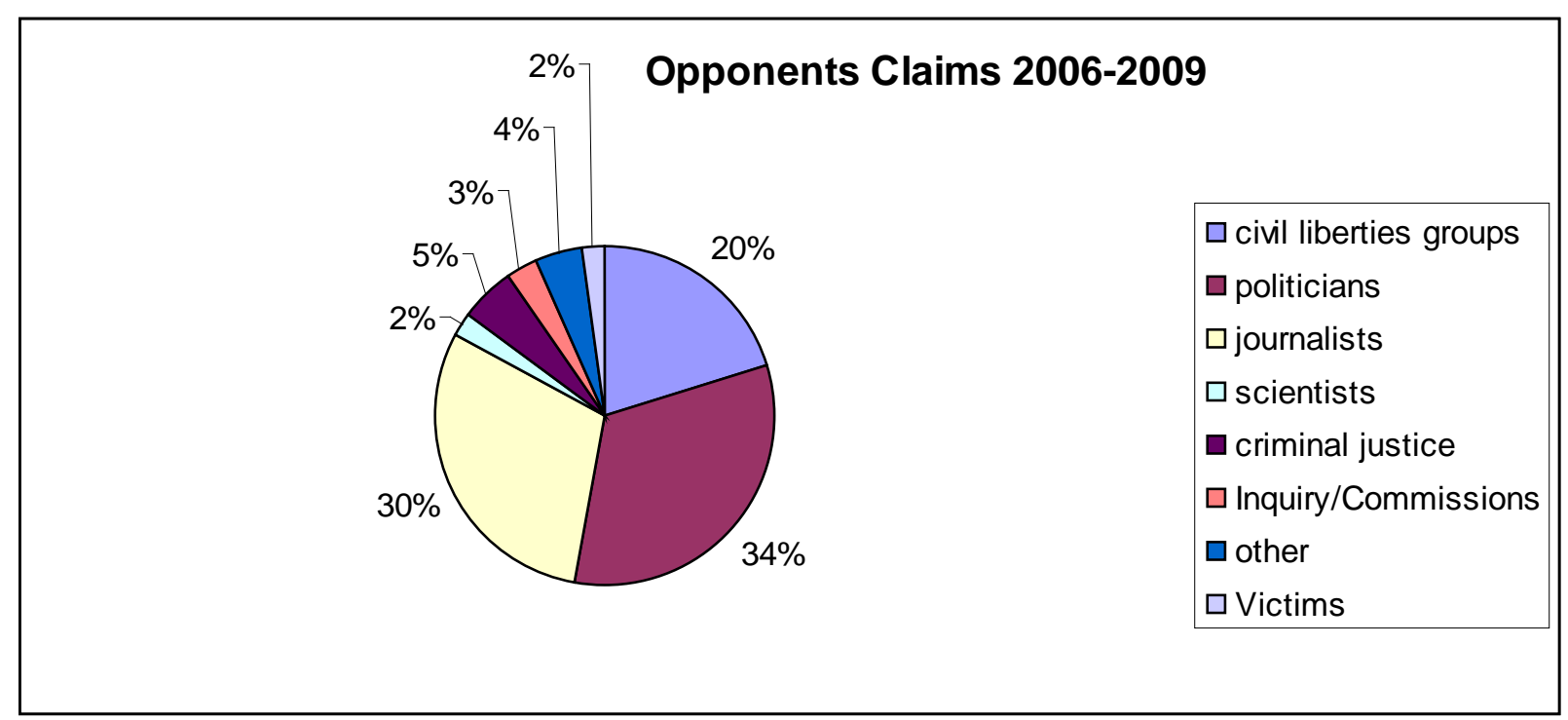

$\mathrm{n}=1101$ 